\title{
Influence of reputation on shareholder value
}

\section{Christopher Runge ${ }^{1, *}$}

${ }^{1}$ Berlin Institute of Finance, Innovation and Digitalization at the Berlin School of Economics and Law, Badensche Straße 50-51, 10825 Berlin, Germany

\begin{abstract}
Research background: This paper focuses on the topic of reputation management. Reputation is a social construct. It is based on a person's opinion of another person, thing, or organization. It is also highly dependent on group interactions and the socio-cultural environment. A good reputation is equated with a high standing and the attributes credibility, honesty, reliability, responsibility, and trust play a major role here. This also applies to companies. The literature offers numerous studies in which the influence of reputation on brand value or company value is examined. Their common tenor is that they lead to the conclusion that essentially a relationship exists between reputation, brand value, and shareholder value.

Purpose of the article: The aim of this paper is to empirically test how reputation can influence shareholder value. As a proxy variable, reputation is represented by the change in the brand value of companies.

Methods In this study, data from the EIKON database of Thomson Reuters and data for brand values from Interbrand were used. For a total of 147 companies, the share prices, sales revenues, EBITDA, and the marketto-book ratio were recorded on the basis of the ISIN. In addition, brand values were summarized for these companies according to Interbrand. It should be noted that the figures varied from year to year, as data was also missing or newly added during the years. Thus, depending on the study, a smaller number than 147 companies were analyzed. Data from 2010 to 2020 were collected and analyzed. In the univariate regression analysis performed, we first tested whether the change in reputation could explain the change in company performance. Subsequently, further regression analyses were conducted to test whether the reputation can explain profit margin and market-to-book ratio.
\end{abstract}

Findings \& Value added: The results show the influence of reputation on selected variables.

Keywords: Shareholder Value ; Reputation, Brand Value

JEL Classification: $\quad G 10 ; G 11 ; G 32$

\footnotetext{
* Corresponding author: c.runge@bettertrust.de
} 


\section{Introduction}

The pursuit of a good reputation is ancient, indeed one of the most important social factors of all. People have always paid attention to their good reputation. Recognition by the community and thus belonging is an almost archaic element of living together in a society up to and especially today. Modern public relations (PR) was invented at the beginning of the last century, although rudimentary precursors already existed in the 19th century. Edward Bernays is considered to be one of the founders of this branch of communication. Public Relations served and still serves to control the image and build the reputation of a company or an individual - outside of classic press relations. Public relations thus includes elements of reputation. But it took several decades for reputation to emerge as a separate communications discipline, which was also scientifically recorded, namely by the reputation pioneer Charles Fombrun. As early as the early 1990s, he also dealt with the topic of reputation management - yet it was hardly widespread in companies and other organizations.

It can be concluded that reputation can have an impact on corporate performance and thus shareholder value. For example, Maretno A. Harjoto / Andreas G.F. Hoepner / Qian Li (2021) show that investing in companies with no reputation risk and selling companies with high reputation risk generate positive abnormal returns. Sven Tischer / Lutz Hildebrandt (2014) analyze the impact of the publication of reputation rankings by the German Manager Magazin on stock prices and find positive and negative announcement effects with respect to upgraded or downgraded companies. As demonstrated above through the history of reputation management, the significance of reputation has evolved drastically. While being originally of importance for every human being individually (Bauhofer and Neubert, 2012), reputation has now been moved into the center of companies' attention.

As demonstrated above through the history of reputation management, the significance of reputation has evolved drastically. While being originally of importance for every human being individually (Bauhofer and Neubert, 2012), reputation has now been moved into the center of companies' attention.

It is next to be investigated how the public perceives companies' reputation and which factors have an influence. For example, York Lunau conducted a study on the German public's expectations for ethical behavior in business practices and found that consumers had some tolerance for necessary measure but were much less forgiving for any unsocial behavior beyond these (Brand Eins, 2004). Analyzing a study on „The Authenticity Gap“(FleishmannHillard and Lepere Analytics, 2012), Ammerland (2014) showed that the average bank customers do not have their expectations met by their experiences and that they even believe their experiences to become worse in the future. One German bank, namely the "Sparkasse", attempted their own creative approach to this problem and eased the dress code policy used in its branches, hoping to appear more approachable to the customers (Die Welt, 2018). However, Stiftung Warentest (2010) had already established that the problems were much more on the qualitative side of the banks' practices, as the majority of banks had been found unable to suggest investment opportunities that matched their customers' needs. Götzpartners (2014) focused on the importance of communication as well, taking a digitalized approach and criticizing that German banks were not meeting their customers' expectations regarding communication via social media channels.

Despite everything that company managers can improve to build a stable and positive reputation, some dangers appear to be out of their control. The internet has not only provided companies with various opportunities to build a reputation (Sünderhauf and Petrov, 2018), it has simultaneously opened many ways a reputation can be ruined. Scherg (2011) explains how slander of private persons' and companies' reputations is carried out in modern digitalized times and gives suggestions on how to avoid this and fight back. 
But is reputation really worth all this detailed effort? The literature suggests that it is. In 1992, Hall defined reputation as a crucial part of any company's intangible assets. The relevance of brand value and how closely it depends on a company's reputation was shown by Schwalbach (2000), who was able to link reputation factors to a company's innovation and communication abilities.

Previously, in 1988, Interbrand and the London Business School already understood the fundamental importance of reputation for brand value and developed the Interbrand brand valuation model, a complex step-by-step concept which built on the idea that a part of a company's value can be found in the existence of its brands alone. The immense popularity of the Interbrand model shows that it served managers' needs for understanding the value of the brand they manage (Stucky, 2004).

Building on this well-known concept, the literature has since presented various methods and models to help managements evaluate and benchmark brand values as a part of reputation management (BBDO, 2001; Hüttl, 2005; Klein-Bölting and Maskus, 2003; Sattler, 2000). Additionally, the individual methods have been analyzed and benchmarked against each other, helping management to find the right reputation management and brand valuation tools for their individual companies and needs (Bentele et al., 2005). The sheer mass of evaluation models and the variety of literature on these serve as proof of the importance of brand value and reputation management for companies.

In the context of this empirical investigation, this paper aims to empirically test the impact of reputation on shareholder value. The market value of Interbrand's enterprise is used as a proxy for corporate reputation. Profitability represented by EBITDA margin and market to book ratio are added as explanatory variables.

\subsection{Reputation Management}

The term "reputation" originates from Latin and means "consideration" or "calculation" in this context. A good reputation is equated with a high standing and the attributes credibility, honesty, reliability, responsibility and trust play a major role here. However, Wüst says, "There is no uniform, generally valid definition for reputation, but many attempts to circumscribe it." (Wüst et al. 2012).

Burkhardt (2008) defines reputation from a business perspective - which this paper will focus on - as the entirety of impressions created among all stakeholders of a company based on past, present, and future aspects. Schwalbach (2000) sees reputation as a company's standing as perceived by outsiders. For companies, reputation counts as an intangible asset and is thus a component of goodwill. It is considered the most important intangible asset in terms of competitive advantage (Hall, 1992).

Related to reputation are the terms image, brand and branding. Reputation and image in particular are used synonymously, but it is important to differentiate between the two, especially from a professional and scientific point of view: Images are ideas that viewers form, a kind of illusion. Reputation, on the other hand, means the summation of these images into an absolute value that ultimately determines perceived quality and sales success. According to Wüst, Charles Fombrun, the doyen of reputation research, places "identity, brand, image and reputation in a complementary and conditional and, above all, shapable context." (Wüst et. al. 2012) Reputation has a more evaluative character and has an internal and external effect. Image, on the other hand, is the perception from an external point of view, is more subject to short-term fluctuations, or can be rapidly changed by corrective campaigns. In this context, it is even possible for a company to have a negative image that relates to individual aspects, but for a company's reputation to be positive. (Wüst et. al. 2012). 


\subsection{Brand value as proxy for reputation}

In the context of numerous mergers and acquisitions in the $1980 \mathrm{~s}$, which revealed the brand-dependent company value, Interbrand developed an overall model for the evaluation of brand value in cooperation with the London Business School in 1988. With the Interbrand approach, more than 5000 brands have been evaluated to date, ranging from simple homogeneous brands to complex brand systems (Stucky, N. (2004), 433 - 434). Brand equity is defined by Interbrand as "the present value of those future earnings that can be attributed solely to the existence of the brand." The Interbrand approach is based on five process steps, as shown in the following figure.

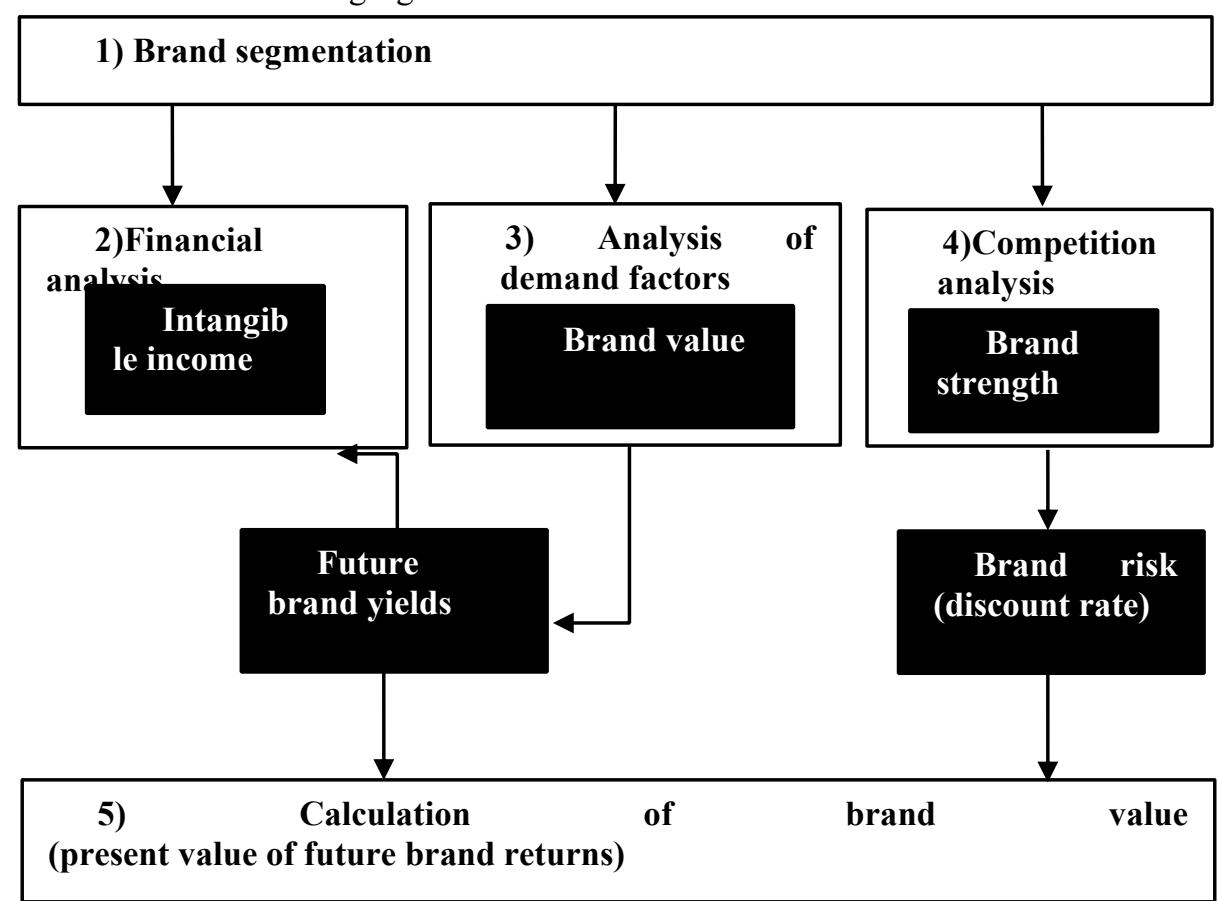

Figure 1. Methodical steps of brand valuation according to Interbrand Source: Stucky, N. (2004), S. 108, TANK AG

\section{Methods}

\subsection{Data}

In the present study, data from the EIKON database of Thomson Reuters and the Brand Values data of Interbrand were used. For a total of 147 companies, the ISIN was used to record share prices, revenues, EBITDA and the market to book ratio. In addition, the brand values for these companies were combined according to Interbrand. It should be noted that the figures varied from year to year as data were also missing or new during the year. Thus, depending on the investigation, a lower number of 57 companies was analyzed. The data for the years 2010 to 2020 were collected and evaluated. Panel data with 627 records were prepared for the statistical analysis. 


\subsection{Research Methodology}

Shareholder value is defined as the $\mathrm{Y}$ variable to be explained in a linear regression model. The focus is on the logarithmized annual return in the period from 2010 to 2020. The share prices of the sample companies at the end of the year from 2009 to 2020 were used for this purpose. Since reputation was defined as brand value, this variable will be the independent $X$ variable. The central question in the analyses is whether reputation can explain shareholder value. Besides reputation, which is represented by the value of brand value of Interbrand companies, profitability, represented by EBITDA margin and market to book ratio are used as additional variables. The EBITDA margin is calculated from the quotient of EBITDA and Sales. Since shareholder value is used as a return variable in the analyses, reputation is also calculated as the annual change in brand value. We use a linear multivariate regression analysis to test the correlations for statistical significance.

\section{Results}

Using the share price return as a proxy for shareholder value is common practice in the literature. Thus, the difficulty in relying on Interbrand brand values seems. Here, however, it is noticeable that the normal use of the values is wrong, because large companies generally following the brand valuation theory of Interbrand - also have larger brand values. Therefore, a relative size must be used at this point. The change of the brand value is calculated according to Interbrand. The Delta Interbrand Value is the predictor in the model.

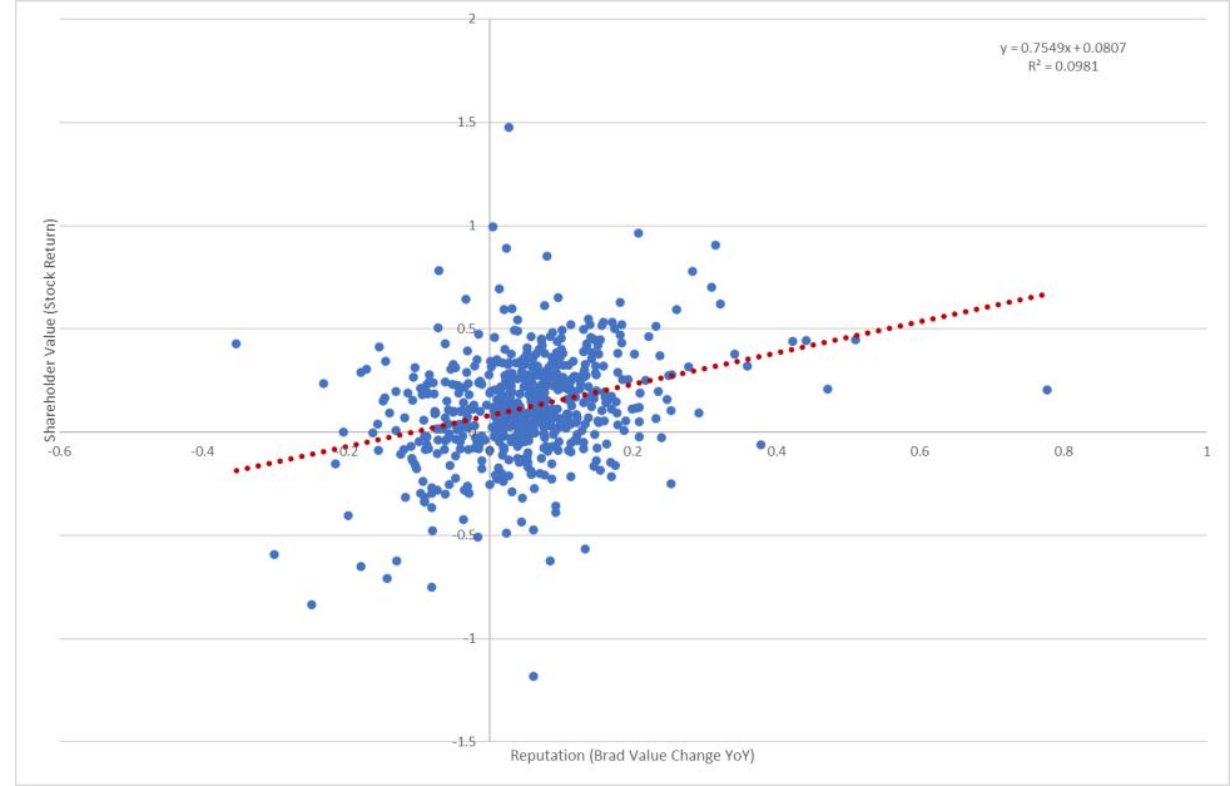

Figure 2. Regression $\mathrm{y}=$ Stock Return, $\mathrm{x}=$ Interbrand Values

Source: Own Calculation

The relationship between reputation and shareholder value is positive and has a corrected $\mathrm{R}$-squared of just under $10 \%$. At the same time, reputation is a significant factor in the change in shareholder value.

Table 1. SPSS Statistic univariate regression predictor Reputation (Band Value Return) 


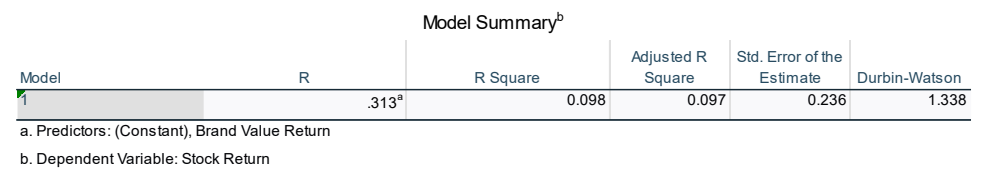

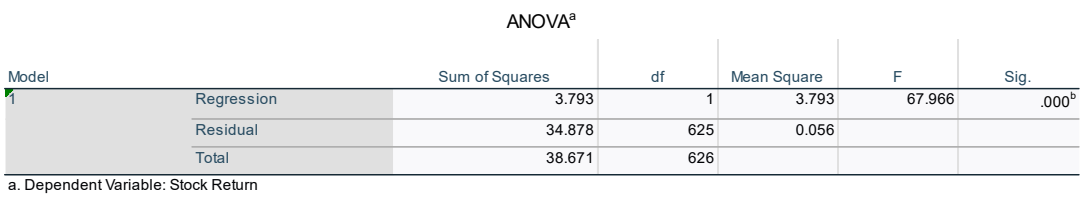

b. Predictors: (Constant), Brand Value Return

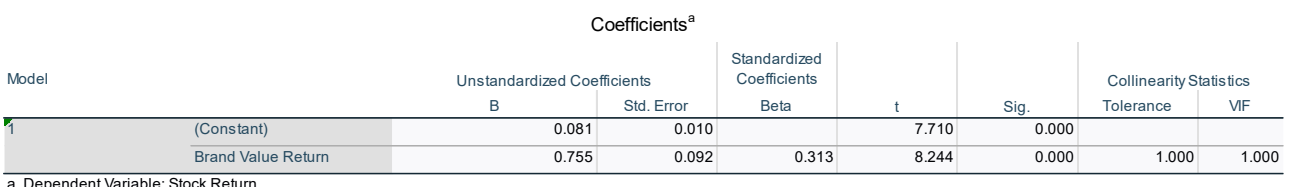

Source: Own Calculations

The consideration of the correlation of the individual model variables shows that this is primarily low positive and significant in a few relationships. EBITDA to Sales, which correlates positively and significantly with both the stock return (Shareholder Value) and the Brand Value Return (Reputation) variables in the model, should be mentioned here as an example.

Table 2. SPSS Statistic correlation matrix

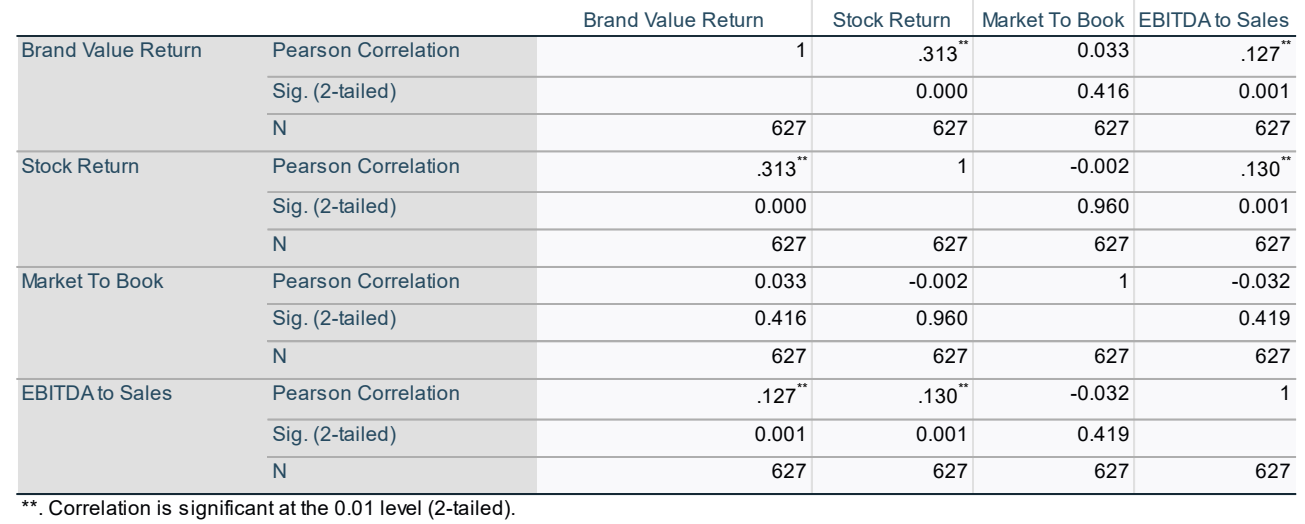

Source: Own Calculations

In the following, a multivariate regression model with the variables Brand Value Return representing Reputation, EBITDA to Sales representing Profitability and Market to Book Ratio was set up. All variables should explain shareholder value. In this model, too, only the reputation and profitability could be determined as a significant variable with a positive impact on shareholder value. Due to the model extension, the R square rise light to $10.2 \%$ only marginally compared to the model above. 
Table 3. SPSS Statistic multivariate regression predictors: Brand Value Return; EBITDA to Sales and Market to Book Ratio

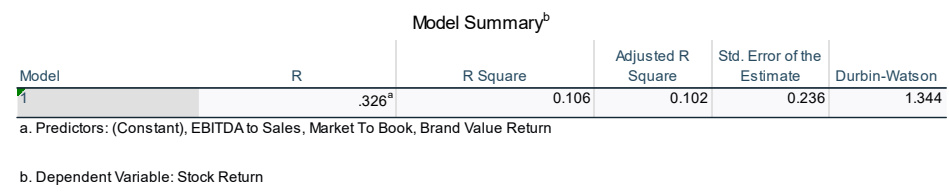

ANOVA $^{\mathrm{a}}$

\begin{tabular}{|c|c|c|c|c|c|c|}
\hline \multirow{4}{*}{ Model } & & Sum of Squares & df & Mean Square & $\mathrm{F}$ & Sig. \\
\hline & Regression & 4.118 & 3 & 1.373 & 24.748 & $.000^{\mathrm{b}}$ \\
\hline & Residual & 34.553 & 623 & 0.055 & & \\
\hline & Total & 38.671 & 626 & & & \\
\hline
\end{tabular}

b. Predictors: (Constant), EBITDA to Sales, Market To Book, Brand Value Return

\begin{tabular}{|c|c|c|c|c|c|c|c|c|}
\hline \multicolumn{9}{|c|}{ Coefficients $^{a}$} \\
\hline \multirow[t]{2}{*}{ Model } & & \multicolumn{2}{|c|}{ Unstandardized Coefficients } & \multirow{2}{*}{$\begin{array}{l}\text { Standardized } \\
\text { Coefficients } \\
\text { Beta }\end{array}$} & \multirow[b]{2}{*}{$t$} & \multirow[b]{2}{*}{ Sig. } & \multicolumn{2}{|c|}{ Collinearity Statistics } \\
\hline & & B & Std. Error & & & & Tolerance & VIF \\
\hline \multirow[t]{4}{*}{1} & (Constant) & 0.038 & 0.021 & & 1.854 & 0.064 & & \\
\hline & Brand Value Return & 0.728 & 0.092 & 0.302 & 7.900 & 0.000 & 0.983 & 1.018 \\
\hline & Market To Book & $-4.142 \mathrm{E}-05$ & 0.000 & -0.009 & -0.234 & 0.815 & 0.998 & 1.002 \\
\hline & EBITDA to Sales & 0.189 & 0.079 & 0.092 & 2.399 & 0.017 & 0.983 & 1.018 \\
\hline
\end{tabular}

Source: Own Calculations

The statistical analysis shows that reputation can have a significant positive impact on shareholder value. In this respect, all companies should regard reputation management as an integral part of corporate management.

\section{Conclusion}

This paper deals with the topic of reputation management. Reputation management is therefore the management of reputation, i.e. a planned activity geared to specific objectives that includes components of controlling. It is recorded, it is evaluated, it is adjusted and it is controlled. In today's digital world, reputation can be seen as an integral part of marketing. In this paper, reputation is equated with the brand value in order to determine the influence of reputation management on shareholder value. Interbrand's model was used as a representative to determine the brand values. It was then examined what influence these had on shareholder value (share price). A positive significant influence of the reputation on the shareholder value could be determined.

\section{References}

1. Ammerland, A. (2014, May 15). Maßnahmen zur Reputationssteigerung. Banken kämpfen um ihren Ruf. Springer Professional. http://www.springerprofessional.de/banken-kaempfen-um-ihren-ruf/5105004.html

2. Bauhofer, B., Neubert, M. (2012). Wie gut ist mein Ruf?. Gabal-Verlag.

3. BBDO (2001). Brand Equity Excellence, Band. 1. Brand Equity Review

4. Bentele, G.; Buchele, M.-S., Hoepfner, J., Liebert, T. (2005). Markenwert und Markenwertermittlung - Eine systematische Modelluntersuchung und -bewertung. Springer Gabler. 
5. Brand Eins (2004). Gute Firma = gute Bürger. Brand Eins. https://www.brandeins.de/magazine/brand-einswirtschaftsmagazin/2004/verantwortung/ gute-firma-guter-buerger

6. Burkhardt, R. (2008). Reputation Management in Small and Medium-sized Enterprises. Analysis and evaluation of the use of reputation management. A survey of small and medium-sized enterprises in Germany. Diplomica-Verlag.

7. Die Welt (2018, August 1): Die Banken hängen den „Spießer-Schlips “ an den Haken. Welt. https://www.welt.de/wirtschaft/article180341448/Dresscode-Sparkassen-lockernden-Dresscode-ihrer-Angestellten.html

8. Fleishman-Hillard (2012). The Authenticity Gap - Managing Expectations and Experience. Fleishman-Hillard. http://cdn.fleishmanhillard.com/wpcontent/uploads/meta/resource-file/2013/authenticity-gap-executive-summary1367433000.pdf

9. Fombrun, C., Shanley, M. (1990). What's in a name? Reputation and Corporate Strategy. Academy of Management Journal 33, 233-258.

10. Götzpartners (2014). Deutsche Banken verlieren den Anschluss bei Social Media. Götzpartnters. http://www.goetzpartners.com/de/presse/news/details/browse /2/article/deutsche-banken-verlieren-den-anschluss-bei-socialmedia/?tx_ttnews[backPid] $=30 \& \mathrm{cHash}=63 \mathrm{f5} 14 \mathrm{e} 3 \mathrm{~d} 94 \mathrm{c} 0 \mathrm{c} 1 \mathrm{a} 34873 \mathrm{a} 36 \mathrm{a} 433 \mathrm{a} 9 \mathrm{~b} 6$

11. Hall, R. (1992). The Strategic Analysis of Intangible Resources. Strategic Management Journal, Jg. 2, 10-17.

12. Harjato, M.A., Hoepner, A.G.F., Li, Q. (2021). Corporate social irresponsibility and portfolio performance: A cross-national study. Journal of International Financial Markets, Institutions and Money, 70, doi: 10.1016/j.intfin.2020.101274.

13. Hüttl, M. (2005). Der gute Ruf als Erfolgsgröße - profitieren Sie von ihrem Ansehen!. Erich Schmidt-Verlag.

14. Klein-Bölting, U., Maskus, M. (2003): Value Brands - Markenwert als zentraler Treiber des Unternehmenswertes -. Schäffer-Poeschel.

15. Sattler, H. (2000): Marken und Markenbewertung in deutschen Unternehmen und deren Auswirkungen auf den Kapitalmark. I: H. Knüppel und C. Lindner (Eds.), Die Aktie als Marke? Wie Unternehmen mit Investoren Kommunizieren sollen. Springer Link.

16. Scherg, C. (2011). Rufmord im Internet - So können sich Firmen, Institutionen und Privatpersonen wehren. Ambition-Verlag.

17. Schwalbach, J. (2000). Image, Reputation und Unternehmenswert. In B. Bearns, J. Raupp (Eds.): Information und Kommunikation in Europa (285-294). Vistas Verlag.

18. Stiftung Warentest (2010). Banken im Test: Die Blamage geht weiter. Finanztest 08/2010. http://www.test.de/Banken-im-Test-Die-Blamage-geht-weiter-4113924-0/

19. Stucky, N. (2004): Monetäre Markenbewertung nach dem Interbrand Ansatz, 2004. In A. Schimansky (Eds.), Der Wert der Marke. Springer Link.

20. Sünderhauf, V., Petrov, S. (2018). Smart David vs Digital Goliath: Wie Sie mit intelligenter Suchmaschinenoptimierung die Großen schlagen. Redline Verlag.

21. Tischer, S., Hildebrandt, L. (2014): Linking corporate reputation and shareholder value using the publication of reputation rankings. Journal of Business Research, 67 (5), 1007 1017. doi: 10.1016/j.jbusres.2013.08.007.

22. Wüst, C., Kreutzer, R. T. (2012). Corporate Reputation Management. Wirksame Strategien für den Unternehmenserfolg. Springer Gabler. 